\title{
Resilience Training of Preschool Children Based on Traditional Folk Games
}

\author{
Daoyuan Li* \\ School of Preschool Education, Changsha Normal University, Changsha 410100, Hunan Province, China \\ *Corresponding author: Daoyuan Li, ldycs@csnu.edu.cn
}

\begin{abstract}
Traditional folk games inherit the history, culture and identity of a country and nation, and they have even more important meanings for China, which has a long history and many ethnic groups. However, with the rapid globalization of modern technology and economy, many Chinese traditional folk games are facing the crisis of disappearing. This article discusses how to develop and utilize the new functions of traditional folk games. That is to use them to train the resilience of preschool children, thus to initiate a new understanding of traditional folk games by teachers and parents. The article firstly discusses the importance of cultivating preschool children's resilience, then analyzes the role of games in cultivating preschool children's resilience, studies the traditional folk game classification method for preschool children's resilience, and gives the development orientation traditional folk game teaching strategies and steps for the cultivation of resilience. This research not only inherits Chinese traditional culture in preschool education, but also trains preschool children's resilience and strengthens their minds. It has important practical significance and reference value for the current training and education of preschool children in China and East Asia.
\end{abstract}

Keywords: Traditional Folk Games; Resilience training; Preschool children

Publication date: August 2021; Online publication: August 30, 2021

\section{Introduction}

China is a country with a long history, so in the development of its history, multi-ethnic and various types of traditional folk games have appeared, such as kite flying, tops whipping, and rubber band jumping. These games have become an important and basic carrier of Chinese traditional culture. While traditional Chinese folk games inherit Chinese culture, history and self-identity, they also play a role in cultivating children in all aspects, including cognitive ability, literacy, calculation ability, social emotion, cultural understanding, physical health, etc.

However, with the rapid development of modern economy and high technology, some ideas and lifestyles have become more rapid globalization, and a large number of traditional Chinese folk games have gradually disappeared from people's sight. The potential dangers are the loss of Chinese culture and history, and the weakening of traditional ideas. In response to the situation, the General Office of the State Council issued "Opinions on the Implementation of the Inheritance and Development Project of Chinese Excellent Traditional Culture" in 2017. The file clearly stated, "the inheritance and development project of Chinese excellent traditional culture should be implemented. It has great practical significance for enhancing the country's cultural soft power, safeguarding national cultural security, inheriting the Chinese cultural heritage, and comprehensively improving the cultural literacy of the people ${ }^{[1]}$."

In recent years, there are many child-self-injury accidents all over the world, which have made the whole society aware of the problems in cultivating children's resilience facing risks and stress. By cultivating children's resilience, children can "recover" and form their own personality qualities with 
adversity in a variety of ways, effectively cope with and overcome the serious difficulties they face, which have also become the consensus of preschool education researchers.

The paper explores the application of Chinese traditional folk games to train the preschool children's resilience, which not only inherits Chinese traditional culture, but also strengthens their minds. It has important practical significance and reference value for the current training and education of preschool children in China and other East Asian counties.

\section{Why we need to train the resilience of preschool children}

Due to young age, strong dependence, and weak self-regulation ability, preschool children are prone to children's psychological barriers, such as solitary, autism, depression, violent tendencies, etc., when they face various crisis factors (for example, domestic violence, parental divorce, school bullying). These barriers not only affect children's future learning and interpersonal communication, but also may cause children to self-harm when mental illnesses are seriously. However, in most developing countries, only physical disease is much accounted of, mental illness and its harm are ignored. According to the statistics, less than $20 \%$ of children will receive related psychological treatment ${ }^{[2]}$.

Resilience is the psychological and physical ability that children develop through life experience and adult demonstrations when facing painful physical or mental conditions. Nan Mo, Chongxin Li, Noble, and other domestic and foreign scholars have given a common definition of resilience, that is an ability to resist actively and overcome adversity, a self-expression and using of his (or her) advantages and resources when an individual responds to a crisis, disaster, pain, pressure or frustration ${ }^{[3,4,5]}$. The World Organization for Preschool Education (OMEP) also believes that resilience can help children to recover from adversity in a variety of ways and form their own personalities. These personality qualities include creativity, sharing and cooperation, respect for others, communication and so on.

Children with resilience will actively accept themselves and others, be creative, and learn to share, cooperate, communicate and solve problems. In other words, resilience helps preschool children to overcome various mental illnesses and becomes an effective means for preschool children to solve the crises. Therefore, cultivating resilience is particularly important for preschool children. Children with strong resilience will have a happier life and will have better performance in future studies and works.

\section{Why Games can Train the Resilience of Preschool Children}

Ginsburg believes that the performance of resilience can be described as 7 "C"s, that is Competence, Confidence, Connection, Character, Contribution, Coping and Control ${ }^{[6]}$. From this point, resilience includes a variety of factors, or the resilience consists of a variety of factors. In the measurement of children's resilience in California ${ }^{[7]}$, the resilience factors are divided into two groups of protective factors, internal and external, as shown in Table 1., and it is believed that the higher the protective factor, the higher the resilience.

Games are widely encouraged in preschool education. Most researches show that games application in preschool education can be beneficial to development of almost all key areas of preschool children, including cognitive ability, literacy, calculation ability, social emotion, cultural understanding, physical health, etc. For example, OMEP believes that games can help children reduce stress, improve brain function, stimulate creativity, make relationships and connections with others better. At the same time, games can make children happy, relax, enhance physical fitness, acquire knowledge and skills, improve social skills, and strengthen emotional control. 
Table 1. Protective factors of children resilience

\begin{tabular}{ll}
\hline External factors & External caring environment \\
& Positive expectations of others \\
& Meaningful participation opportunities \\
\hline External factors & Ability of communication and cooperation \\
& Ability to empathize \\
& Ability of analyzing on and solving problems \\
& Self-confidence \\
& Self-control \\
& Sense of purpose \\
\hline
\end{tabular}

Through game activities, preschool children can get benefits ${ }^{[2,8,9]}$ include:

(1) Communication and negotiation skills of preschool children can be exercised in group games.

(2) In the game, preschool children can try and learn new skills, practice overcoming difficulties, train preschool children for problem-solving skills, and help children build self-confidence.

(3) Preschool children's participation of decision-making in games can help them gain a sense of accomplishment, train self-confidence and self-control, and enhance self-awareness and awareness of others.

(4) Certain adversities in the game help preschool children imitate reality to overcome difficulties and obstacles.

It can be seen that games can provide preschool children with protective factors to train resilience, including establishing interpersonal relationships, cultivating safety and harmony, promoting task completion, accumulating positive experiences, discovering opportunities and conducting meaningful interactions, which greatly promotes children cultivation of resilience. Hong Kong scholar, Xiong Jiahuan studied the use of games to promote the positive development of children's needs in various aspects, and proposed the impact of games on children's resilience-optimism, resilience-connection, and resilienceability ${ }^{[10]}$. OMEP carried out a "Play \& Resilience" study, focusing on cultivating children's resilience, and raising issues that need attention and consideration. East China Normal University in China participated in the project's research.

Game teaching has powerful shaping ability to focus on cultivating the preschool children resilience, and help preschool children overcome various negative effects of physical, emotional, and communication, so that they can develop healthier enough to face different challenges without triggering various psychological disease. This will have important significance and research value for the training and education of preschool children in China, including other developing countries.

\section{How to Choose Traditional Folk Games for the Training of Preschool Children's Resilience}

There are 56 ethnic groups in China. In the process of forming their own cultures, various ethnic groups have created various types of traditional folk games. These different kinds of folk traditional games are used in preschool children's education, which promotes the progress of children's different characteristics and skills of resilience, and supports children's learning and development in different fields. Therefore, for the training of preschool children's resilience, kindergarten teachers need to consciously recognize and distinguish, and then select and improve different types of games to promote the cultivation of children's resilience.

There are many ways to classify preschool children's games. Aiming at the cultivation of preschool children's resilience, this article attempts to divide folk games into 5 types, as shown in Table 2. The table 
gives the meaning of various games and the cultivation of children's resilience, and provides game examples for explanation.

It should be noted that each type of folk games can help preschool children develop different characteristics and skills in resilience. Different types of games have some similarities with each other. For example, "body" games also contain some aspects of "symbolic" games.

If fully understanding the differences between the five types of games, kindergarten teachers can design game teaching methods to train children's resilience, and ensure that the designed games can provide preschool children with opportunities to expand their learning. And then preschool children can engage positive in the games through their imagination and creativity, they will feel happy in the game and develop the ability to deal with risks.

Table 2. Classification of traditional folk games and training of preschool children's resilience

\begin{tabular}{|c|c|c|c|c|}
\hline No & Game types & Game connotation & Affect to resistance & Examples \\
\hline 1 & $\begin{array}{l}\text { Sports } \\
\text { games }\end{array}$ & $\begin{array}{l}\text { It is mainly divided into } 2 \\
\text { types, big action games and } \\
\text { fine action games. These } \\
\text { games can promote the } \\
\text { development of children's } \\
\text { body coordination and hand- } \\
\text { eye coordination. Among the } \\
\text { activities of } 4-5 \text { age children, } \\
\text { sports games usually account } \\
\text { for about } 20 \% \text {. }\end{array}$ & $\begin{array}{l}\text { (1) Preschool children can learn the self- } \\
\text { development skills by taking risks in a safe } \\
\text { environment, which support the cultivation of } \\
\text { self-confidence and abilities. } \\
\text { (2) Sports games can help preschool children to } \\
\text { establish good social relationships and acquire } \\
\text { skills that support social emotions. } \\
\text { (3) It can help preschool children strengthen their } \\
\text { sense of cultural identity and enhance national } \\
\text { self-confidence. For example, you can integrate } \\
\text { traditional Chinese literary works, music, etc. }\end{array}$ & $\begin{array}{l}\text { Mice steal } \\
\text { oil, Eagle } \\
\text { catches } \\
\text { chicken, } \\
\text { Three-legs } \\
\text { race, Rubber } \\
\text { band } \\
\text { skipping }\end{array}$ \\
\hline 2 & $\begin{array}{c}\text { Symbolic } \\
\text { game }\end{array}$ & $\begin{array}{l}\text { Using "pretend" objects or toys } \\
\text { to represent objects in real life, } \\
\text { preschool children can express } \\
\text { themselves fully, use } \\
\text { themselves as experimental } \\
\text { objects, and engage in and } \\
\text { pursue the game activities and } \\
\text { themes which they are } \\
\text { particularly interested in. }\end{array}$ & $\begin{array}{l}\text { (1) Preschool children can explore their own } \\
\text { interests autonomously, make corresponding } \\
\text { decisions, and enhance their control sense. } \\
\text { (2) Through contact with the simulated real } \\
\text { environment, preschool children develop various } \\
\text { abilities such as listening, speaking, reading, } \\
\text { writing, and calculation, and enhance their self- } \\
\text { confidence. } \\
\text { (3) The positive feelings brought by the game } \\
\text { improve preschool children's happiness, } \\
\text { enhance their sense of identity and belonging, } \\
\text { and make them more willing to explore the world } \\
\text { around them. } \\
\text { (4) Engagement in music activities of symbolic } \\
\text { games significantly promotes the development } \\
\text { of preschool children's communication, } \\
\text { creativity, self-discipline and cooperation } \\
\text { abilities. }\end{array}$ & $\begin{array}{c}\text { Stretch saw, } \\
\text { Top of the } \\
\text { pot }\end{array}$ \\
\hline
\end{tabular}




\begin{tabular}{|c|c|c|c|c|c|}
\hline 3 & $\begin{array}{l}\text { Operation } \\
\text { games }\end{array}$ & $\begin{array}{l}\text { One of the most common game } \\
\text { types. Using their creativity, } \\
\text { imagination and motor skills, } \\
\text { preschool children experiment } \\
\text { and manipulate the discovered } \\
\text { objects, enhance their sense of } \\
\text { exploring objects and } \\
\text { materials, and experience } \\
\text { action behaviors. }\end{array}$ & $\begin{array}{l}\text { (1) } \\
\text { (2) } \\
\text { (3) }\end{array}$ & $\begin{array}{l}\text { Through interacting with different objects, } \\
\text { preschool children have the opportunity to } \\
\text { participate in different sensory experiences. } \\
\text { These will bring various benefits, such as } \\
\text { working together to promote children's mutual } \\
\text { relationship. } \\
\text { Understanding objects with important culture or } \\
\text { other values in the operation game, children are } \\
\text { encouraged to establish recognition of culture, } \\
\text { beliefs, etc., and increase the sense of identity } \\
\text { and responsibility. } \\
\text { By setting goals and challenges, conceiving new } \\
\text { methods and manipulating objects to achieve, } \\
\text { operational games can help preschool children to } \\
\text { develop their problem-solving abilities, } \\
\text { reasoning abilities and other acquired cognitive } \\
\text { skills. }\end{array}$ & $\begin{array}{l}\text { Hopscotch, } \\
\text { Chinese rope } \\
\text { weaving }\end{array}$ \\
\hline 4 & $\begin{array}{c}\text { Pretend } \\
\text { games }\end{array}$ & $\begin{array}{l}\text { The game played in a certain } \\
\text { role, including roles other than } \\
\text { the children's own experience } \\
\text { and background. }\end{array}$ & $\begin{array}{l}\text { (1) } \\
\text { (2) } \\
\text { (3) }\end{array}$ & $\begin{array}{l}\text { Pretend games provide children with multiple } \\
\text { opportunities to develop skills and } \\
\text { characteristics related to resilience. } \\
\text { This type of game usually involves preschool } \\
\text { children playing adult roles and cooperating with } \\
\text { their peers to determine the "rules" of the game, } \\
\text { so they can begin to learn to take care of others' } \\
\text { feelings during the game and develop a sense of } \\
\text { responsibility. } \\
\text { In pretend games, preschool children are } \\
\text { provided with opportunities to experience stress } \\
\text { and develop effective coping skills in a risk-free } \\
\text { environment. For example, conflicts between } \\
\text { roles and rules sometimes occur in role-playing } \\
\text { situations, so preschool children will negotiate } \\
\text { roles and identities, so as to learn to cooperate } \\
\text { and support each other. }\end{array}$ & $\begin{array}{l}\text { Pick up } \\
\text { Cotton, } \\
\text { Yamen and } \\
\text { thieves }\end{array}$ \\
\hline 5 & Rule games & $\begin{array}{l}\text { Rule games can lay a good } \\
\text { foundation for preschool } \\
\text { children to display, explore, } \\
\text { and perceive the rules and } \\
\text { standards of the surrounding } \\
\text { social environment. } \\
\text { Children are very interested in } \\
\text { rules and often invent some } \\
\text { rules themselves. }\end{array}$ & $\begin{array}{l}\text { (1) } \\
\text { (2) } \\
\text { (3) }\end{array}$ & $\begin{array}{l}\text { Rules games play a significant role in improving } \\
\text { children's problem-solving skills, because this } \\
\text { game requires children to focus on a task, learn } \\
\text { rules and use these rules to win, thereby } \\
\text { developing their persistence and attention. } \\
\text { When playing rules games with friends, siblings, } \\
\text { and parents, children learn a lot of social skills } \\
\text { about sharing, taking turns, and understanding } \\
\text { the opinions of others. } \\
\text { Rules games also develop various social } \\
\text { relationships, exercise problem-solving skills, } \\
\text { and participate in teamwork. }\end{array}$ & $\begin{array}{l}\text { Drum-and- } \\
\text { pass game, } \\
\text { wooden man }\end{array}$ \\
\hline
\end{tabular}




\section{Realization of Traditional Folk Games Teaching for Preschool Children's Resilience Training}

In order to develop folk traditional game teaching for preschool children's resilience training, work needs to be carried out in the following four aspects:

(1) Arrangement and improvement of the folk game materials

Folk games are diverse. But from the perspective of preschool education and resilience training, not all folk game materials are suitable. Therefore, teachers should collect various game materials widely by interviews, surveys, data analysis, network queries and folk collections. And then, teachers should sort out and improve the game activities suitable for children of different ages, ensure the games applicability in cultivating the resilience of preschool children.

(2) Characteristic analysis and classification of games

Traditional games, which are collected, sorted and improved, should be discussed and analyzed the characteristics and activity methods with other teachers. And then, teachers should clarify what kind of cooperation is needed for children, what issues need to be paid attention to in the game implementation process according to the focus of preschool children's resilience training, ensure the games effectiveness in cultivating the resilience of preschool children.

(3) Establishment of game teaching environment

The implementation of game teaching activities is inseparable from the game environment, so the folk game teaching oriented to the resilience cultivation in the paper. Kindergarten teachers need to pay attention to the establishment of the game environment, and effectively integrate the teaching activity resources inside and outside the kindergarten. So preschool children have the opportunity to get in touch with a variety of folk game activities, more people in society re-recognize folk game activities. In this way, folk games will come into the public's view again, and games will be inherited so as to promote the inheritance of folk games.

(4) Design and implementation of game teaching

The teaching design and implementation process of traditional folk games for resilience training can be designed as shown in Figure 1. ${ }^{[11]}$. First of all, it is necessary to clarify what the teaching goals of the game teaching are carried out, what risk factors are needed to help preschool children to overcome, and what characteristics of resilience should be established. Secondly, according to the teaching goals, teachers select appropriate materials from the folk game material library, organize and carry out the design of game teaching, including background design, character design, rule design, plot design, etc. Finally, teachers carry out game teaching implementation and teaching reflection, evaluate the teaching effect, and reasonably modify the teaching process and game design 


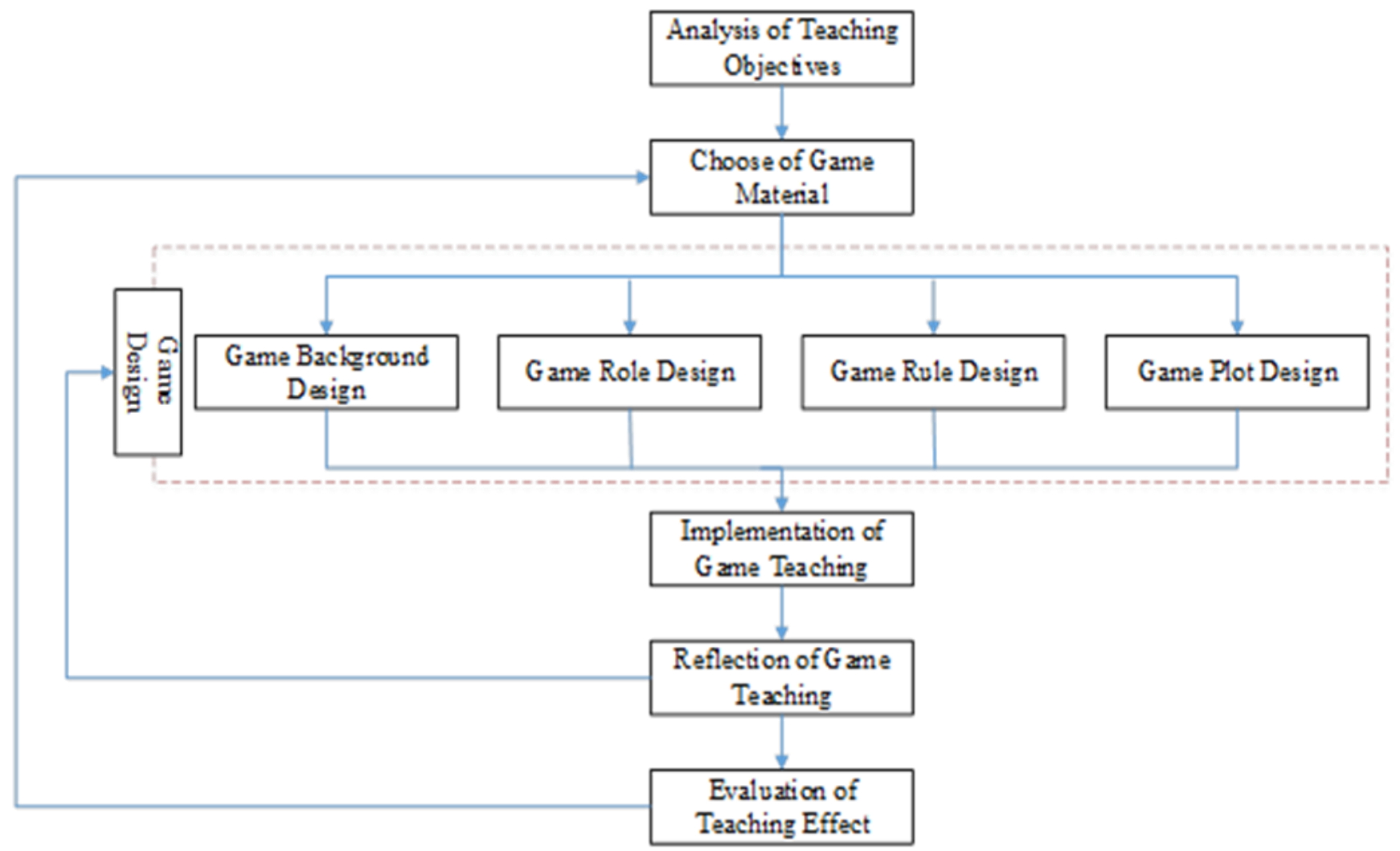

Figure 1. Teaching design of traditional folk games for resilience training

\section{Conclusion}

The paper discusses mainly the use of traditional Chinese folk games to train the resilience of preschool children. The paper studies the importance of cultivating preschool children's resilience and the role of games in cultivating preschool children's resilience, gives a classification method of folk traditional games for resilience training, and summarizes a way for preschool children's resilience training strategies and steps for the teaching of traditional folk games.

At present, the project is under further in-depth study. However, judging from the current results, the cultivation of certain characteristics of preschool children's resilience is still worthy of satisfaction and gratification.

\section{Funding}

This work was supported by the 2020 Scientific Research Project of Hunan Provincial Education Department “The Application of Chinese Traditional Folk Games in Cultivating Preschool Children's Resilience" (Project number: 20C0126).

\section{Disclosure statement}

The author declares no conflict of interest.

\section{References}

[1] Central People's Government of the People's Republic of China. The general office of the CPC Central Committee and the General Office of the State Council Issued the Opinions on the Implementation of the Project of the Inheritance and Development of Chinese Excellent Traditional Culture. http://www.gov.cn/zhengce/2017-01/25/content_5163472.htm. 
[2] OMEP, n.d, Play and Resilience Project. http://www.worldomep.org/index.php?hCode =ACTION_04_02_01.

[3] Noble T, McGrath H, 2012, Wellbeing and Resilience in Young People and the Role of Positive Relationships. Berlin: Springer Science and Business Media.

[4] Na Mo, 2018, Review on the Research of Resilience Theory. Yangtze River series, (9): 159.

[5] Chongxi L, Jufen W, 2018, Western Family Resilience Theory: Connotation, Model and Practical Application. Journal of Nanjing College for Population Programme Management. 34(2): 88-100.

[6] Ginsburg KR, et al., 2015, Building Resilience in Children and Teens: Giving Kids Roots and Wings. Elk Grove Village, IL: American Academy of Pediatrics.

[7] Xiaopin X, Guoxiu T, et al., 2014, A Study on the Applicability of the Chinese Version of the Resilience Test for Children and Adolescents in Beijing. China Youth Study, (5): 5-10.

[8] Jiahuan X, 2017, Game and Resilience. http://openknowledge.wixsite.com/openknowledge/singlepost $/ 2017 / 04 / 05 /$.

[9] Jiasi Z, 2020, Value of Children's Folk Games in Early Childhood Education. Ji Chu Jiao Yu Lun Tan. 13(4): 65-6.

[10] Pi M, 2020, Suggestions on the Application of Shui Folk Game in Kindergarten Education Activities. Education Teaching Forum. 5(1): 361-2.

[11] Cai L, 2018, Effects of Building Block Games on Cognitive Development of Preschool Children. Journal of South China Normal University (Social Science Edition). 9(5): 89-95. 